\title{
Improving teaching effectiveness through transformational leadership and integrity
}

\author{
Masduki Ahmad ${ }^{1}$, Heni Rochimah ${ }^{2}$ \\ ${ }^{1}$ Faculty of Education, State University of Jakarta, Indonesia \\ ${ }^{2}$ Faculty of Teacher Training and Education, As-Syafiiyah Islamic University, Indonesia
}

\begin{abstract}
Article Info
Article history:

Received Feb 24, 2021

Revised Aug 23, 2021

Accepted Sep 9, 2021

Keywords:

Integrity

Teaching effectiveness

Transformational leadership

ABSTRACT

The study aimed to determine the impact of transformational leadership and integrity on the performance of a company. The research sample was 123 lecturers at As-Syafi'iyah Islamic University, Indonesia. The analysis model of this study was a path analysis. Observation and questionnaires were used to obtain the research data. Teaching effectiveness measures how well educators' instruction aligns with learning objectives and provides the best possible outcomes for students who are taking the course. Hypothesis testing was performed using the t-test. The SPSS software version 25 was applied in statistical calculations. The results showed that transformational leadership and integrity have direct and positive impact on the teaching effectiveness. Transformational leadership has a direct and positive impact on the integrity. It is suggested to implement the better transformational leadership to achieve the better the teaching effectiveness.
\end{abstract}

This is an open access article under the CC BY-SA license.

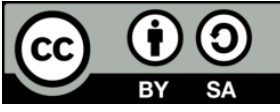

\section{Corresponding Author:}

Masduki Ahmad

Faculty of Education

State University of Jakarta

Rawamangun, Pulo Gadung, East Jakarta 13220, Jakarta, Indonesia

Email: masduki@unj.ac.id

\section{INTRODUCTION}

Education is an opportunity to change people's physical and spiritual capacity according to society's values. Sarid defines education as a continuous process consisting of purposefully organized learning processes aimed at achieving ends that are deliberately extracted from a particular perception of what is good [1]. Education is intended to develop cognitive aspects (e.g., the development of science and intellectuality), development of attitudes (e.g., values, morality, and religion, developing emotions and sensibilities), and the development of practical competencies (including social adaptability and sensitivity to social problems).

Education is also a means to enhance the individual and social capacities of each person. Individually, education will expand knowledge and skills, which is an essential asset in life. Socially, education provides skills to socialize, adapt, interact, foster tolerance, and instill an attitude of appreciation for the pluralism in society. Even on a large scale, education plays a role in developing the economy and society of a country. Simply put, education is a milestone in the development of a country [2]. Moran said that education also prepares students for the future [3], which means that education helps a person solve complex problems. These notions signify that education must be carried out to develop every aspect in a balanced manner. Education that prioritizes intellectuality by ignoring other aspects is limiting the nature of education itself. Such an education concept results in imbalanced skills.

Paying attention to and applying humanity principles in higher education (as well as the sustainable culture and empowerment of Indonesia) play a major role in national education. These aspects also promote 
science and technology. Higher education requires educational institutions that strive to cultivate the capacity of students to become human beings who believe and fear God Almighty and have noble, good, intelligent, capable, imaginative, autonomous, and qualified characters. It is also worth mentioning that producing quality graduates who are experts in science and technology enhance the nation's competitiveness. Komoldit, Tawisook, and Pilanthananond stated that Universities play a critical role in preparing graduates to enter the workforce and contribute to national growth in the short and long term [4].

An appropriate curriculum is needed to attain the goal. Apart from quality learning facilities and infrastructures, central to higher educational institutions is the lecturer. Lecturers as professional educators and scientists are responsible for shaping, improving, and disseminating science and technology through education and community service. Lecturers plan the implementation of the predetermined curriculum through a series of lecture activities. Effective lectures promote conducive teaching conditions, thus optimizing students' potentials. Kola, Sunday, and Ayinde stated that teachers' ability to arrange classrooms and control student behavior is critical to attaining effective educational outcomes [5].

Teaching effectiveness in several private universities has not been maximized. Such an issue blames the low effectiveness of lecturers' teaching; this is based on the findings of a study conducted at one private university in Indonesia, As-Syafi'iyah Islamic University. The preliminary observation reported many indications that the teaching conducted by lecturers at As-Syafi'iyah Islamic University was ineffective. One of the issues was lecturers' inability to keep up with technological development or the learning media. The lecturers must learn how to use technology at a fundamental level and how to incorporate and apply it into their curriculum [6]. In fact, they need on-going assistance in using technology in learning [7]. As Indonesia is struggling with the COVID-19, all learning activities, including in tertiary institutions, must be carried out online. Such a limited educational activities are detrimental to students' education, social life, and mental health [8]. This problem requires lecturers to use learning media that can support online learning systems. However, some lecturers have low mastery of technology, thus hindering the conduct of learning activities and resulting in low teaching effectiveness. This concern is also detrimental to all related parties.

Teaching and learning activities are categorized effective if the educator succeeds in achieving the set targets [9]. The effectiveness of teaching is something that must be considered for every educator. Competent educators are known for their capabilities and experiences in the classroom activities and other activities outside the class (including providing timely reviews and encouraging student collaboration) [10]. In other words, effective teaching activities are not only limited to providing materials and assignments, but also encouraging students to be more active. Professional teachers capable of managing and handling the teaching and learning process are key to effective teaching [11]. This notion signifies that a teacher must have good classroom management skills in order for learning to run effectively. All teachers should strive for effective classroom management and the development of a healthy classroom environment [12]. However, there are some common problems in achieving effective teaching. Among the examples are ineffective instructional strategies, poor class curriculum, and teachers' inability to create a comfortable and safe learning atmosphere [13]. If these problems still persist, effective teaching will not be achieved.

Onyekuru and Ibegbunam explained that teaching effectiveness is demonstrated by intellectual stability, social and emotional stability, a sense of caring for students and a positive view of their profession, and the ability to bring out the best in students [14]. This idea means that the effectiveness of teaching can be seen from the abilities of the lecturers themselves. Positive characteristics of teaching will appear in a lecturer who shows that s/he can teach effectively. Teaching effectiveness can also be defined as a teaching activity with various characteristics that are structured to change students' behavior for the better and according to the pre-set teaching goals to increase students' achievement [15]. Simply put, teachers' quality is seen from their teaching performance and the achievements of students. Arifani, et al. further add that the effectiveness of teaching can usually be seen from a multi-dimensional perspective, such as professionalism, pedagogical abilities, and social and personality traits [16]. From the previous opinions, it can be concluded that teaching effectiveness is a measurement of how well educators' instruction aligns with learning objectives and provides the best possible outcomes for students who are taking the course.

One of the contributing factors to the effectiveness of lecturers' teaching is transformational leadership. Leadership is the power of an individual to influence other people [17]. School leadership plays a vital role in enhancing learning outcomes by boosting lecturers' motivations and skills, as well as the atmosphere of the school [18]. The performance of lecturers as educators in tertiary institutions is undoubtedly determined by the people around them, one of whom is the college leader. The study program's director is the leader in this situation; the leader significantly contributes to every lecturer's decision and performance in providing instruction. The leadership of principals in improving the performance of teachers or subordinates is central to the quality of education in schools [19]. Quality leadership positively influences organizational members, in this case, the lecturers. One common form of leadership found in many leaders in an organization is transformational leadership. Transformational leadership determines the relationship 
between superiors and subordinates [20]. This aspect undoubtedly results in efficient learning with transformational. A transformational leader is responsible for ensuring that each team member can effectively complete the assigned work [21]. This notion means that the effectiveness of the work carried out by someone can be reached by implementing transformational leadership.

Transformational leadership is a leadership style that motivates employees to develop and excel at high levels in performance beyond what they previously expected [22]. Transformational leadership supports people around them, so they can develop further. Lai, et al. opined that members' attitudes might be changed by transformational leaders who encourage them to meet expectations [23]. Transformational leadership is mainly about how leaders exert their influence on followers [24]. A person with transformational leadership quality is willing to accept change and demonstrates proactive behavior [25]. This notion signifies that a transformational leader is not bound by rigid rules and is more adaptable to changes in the environment. Transformational leadership is a leadership style that aims to expand the boundaries of a group and make them perform beyond the status quo, thus helping the group achieves new goals [26]. Transformational leadership emphasizes a clear vision and mission statement, effective communication, attention to organizational members, and providing intellectual stimulation [27]. Transformational leadership can be defined as a change-oriented leadership style; this aims to achieve the organization's goals by applying the principles of involvement, effective communication, and a flexible attitude to change.

Apart from transformational leadership, another contributing factor of teaching effectiveness is integrity. Behavioral integrity and trust factors are triggers for improving the performance of quality human resources [28]. In this case, lecturers who perform good contributes to the classroom success. Isjoni, Daud, and Azhar claimed that good teaching is not about technique. Quality teaching comes from the identity and integrity of the teacher [29]. This idea signifies that even skillful teachers will find it challenging to show their best performance if they do not have integrity. It is of paramount importance for teachers to behave and act with integrity to provide role models for students, thus preventing academic dishonesty [30]. Integrity is one of the attributes a lecturer must have, given his or her status as a quality educator.

Integrity can be defined as the act of thinking, saying, and behaving properly, and upholding the code of ethics and moral principles, resonating to the quality of being honest [31]. Integrity is often defined as a person's honest attitude. According to Oktavia, integrity is the ability to accept unintentional mistakes and differences of opinion honestly; however, integrity cannot accept fraud [32]. Further, Al-Abrrow, Abdullah, and Atshan opined that integrity is a perception that stems from moral principles that differ from person to person [33]. Integrity is frequently linked to applicable norms or rules. Integrity can be seen as a quality of action that is relevant to moral values, norms, and rules [34]. From the previous statements, it can be concluded that integrity is a strong and consistent attitude towards values, morals, and rules in making any decisions or actions.

Based on some of the previous problems, the researcher realized that there were still many concerns in education in tertiary institutions, especially related to teaching effectiveness. Issues in teaching effectiveness will result in low quality of learning received by students. This situation is detrimental to many parties. This research is therefore expected to find solutions to the issues previously mentioned.

\section{RESEARCH METHOD}

The quantitative research approach was used in this study. The study population consisted of 177 permanent lecturers at As Syafi'iyah Islamic University, Indonesia. Of the total population, 123 lecturers were selected randomly as the sample using the Slovin formula with a 5\% error rate. All data were retrieved using observation and closed questionnaires with a Likert scale. The instrument that was distributed to respondents had previously been tested to ensure its validity and reliability.

Path analysis was employed to determine the influence of variables. The initial step was intended to test the prerequisite analysis by testing for normality and linearity. Furthermore, the t-test was carried out to test the hypothesis. All statistical tests in this study were carried out with the help of SPSS version 25 software.

\section{RESULTS AND DISCUSSION}

\subsection{Result}

The prerequisite analysis test in this study consisted of normality and linearity tests. The Kolmogorov-Smirnov formula was applied in the normality test. If the value is Asymp., the normality test is satisfied. The data are presumed to be regularly distributed if the Sig. (2-tailed) is greater than 0.05. The following results are obtained after the calculation are presented in Table 1. 
Based on the results, the Asymp. Sig. (2-tailed) is 0.061. Since 0.061>0.05, it is acceptable to claim that the data in this study were distributed normally. The linearity test was performed after the normality check. This test aims to identify whether or not the variables have a linear relationship. Based on the calculations using SPSS version 25, the following results are obtained and presented in Table 2.

Table 1. Normality test with SPSS version 25

\begin{tabular}{ccc}
\hline & & Unstandardized residual \\
\hline $\mathrm{N}$ & & 123 \\
Normal parameters & Mean & 0.000 \\
& Std. Deviation & 8.672 \\
Most extreme differences & Absolute & 0.078 \\
& Positive & 0.048 \\
& Negative & -0.078 \\
Statistical test & & 0.078 \\
Asymp. Sig. (2-tailed) & & 0.061 \\
\hline
\end{tabular}

Table 2. Linearity test between transformational leadership variables and teaching effectiveness with SPSS

\begin{tabular}{ccccccc}
\multicolumn{7}{c}{ version 25 } \\
\hline Between groups & Sum of squares & Df & Mean square & F & Sig. \\
& (Combined) & 5457.371 & 40 & 136.434 & 1.253 & 0.193 \\
& Linearity & 2488.799 & 1 & 2488.799 & 22.64 & 0.000 \\
Within groups & Deviation from linearity & 2968.572 & 39 & 76.117 & 0.699 & 0.891 \\
Total & & 8925.995 & 82 & 108.854 & & \\
\hline
\end{tabular}

Conclusions can be drawn by looking at the deviation from the linearity value, which reaches 0.891 . Since $0.891>0.05$, it can be concluded that the variables of transformational leadership and teaching effectiveness have a linear relationship. After that, we can see the result of linearity test between the integrity and teaching effectiveness are presented in Table 3. Table 3 shows that the deviation from linearity value is 0.401 . Because $0.401>0.05$, it can be concluded that the variables of integrity and teaching effectiveness have a linear relationship. The normality test and linearity test results show that the prerequisite tests for the path analysis model in this study have been fulfilled.

The following hypotheses are examined in this study: i) Transformational leadership has a positive and significant direct effect on teaching effectiveness; ii) Integrity has a positive and significant direct effect on teaching effectiveness; and iii) Transformational leadership has a positive and significant direct effect on integrity. The results of the path coefficient calculation in the primary model of this study are presented in Table 4 . We can also see the value of the coefficient of determination from this study in Table 5.

Table 3. Linearity test between the integrity and effectiveness of teaching variables with SPSS version 25

\begin{tabular}{|c|c|c|c|c|c|}
\hline & & Sum of squares & Df & Mean square & $\mathrm{F}$ \\
\hline \multirow[t]{3}{*}{ Between groups } & (Combined) & 7388.805 & 36 & 205.245 & 2.524 \\
\hline & Linearity & 4365.751 & 1 & 4365.751 & 53.678 \\
\hline & Deviation from linearity & 3023.053 & 35 & 86.373 & 1.062 \\
\hline Within groups & & 6994.561 & 86 & 81.332 & \\
\hline Total & & 14383.366 & 122 & & \\
\hline
\end{tabular}

Table 4. Research model path coefficient with SPSS version 25

\begin{tabular}{ccccc}
\hline Path & Correlation coefficient & Path coefficient & t-count & Sig. \\
\hline X1X3 & 0.416 & 0.257 & 3.316 & 0.001 \\
X2X3 & 0.551 & 0.463 & 5.962 & 0.000 \\
X1X2 & 0.343 & 0.343 & 4.013 & 0.000 \\
\hline
\end{tabular}

Table 5. Model summary

\begin{tabular}{cccc}
\hline $\mathrm{R}$ & $\mathrm{R}$ square & Adjusted R square & Std. Error of the estimate \\
\hline 0.602 & 0.362 & 0.351 & 8.745 \\
\hline
\end{tabular}


The significance value of each variable can be determined using the data in Table 4 . The direct effect between variables can be seen by examining this value of significance. Since the worth of significance for transformational leadership on teaching effectiveness is 0.001 , and it is less than 0.05 , it is possible to conclude that transformational leadership has a direct and positive impact on teaching effectiveness. The hypothesis can be seen in addition to the significance value by looking at the $\mathrm{t}$-count where $\mathrm{t}$-count $>\mathrm{t}$-table. Because the t-count of the variable $\mathrm{X} 1$ to $\mathrm{X} 3$ is 3.316 , $\mathrm{t}$-table (123) at the 0.05 significance level is 1.980 . This means that $\mathrm{t}$-count $>\mathrm{t}$-table. As $\mathrm{t}$-count $>\mathrm{t}$-table, the hypothesis is accepted, implying that transformational leadership has a positive and significant impact on teaching effectiveness. According to the calculation, the path coefficient value $(\rho 31)$ is 0.257 , and the correlation coefficient (r13) is 0.416 .

Table 4 also shows the impact of the integrity variable on teaching effectiveness. The value of significance of the integrity on teaching effectiveness is 0.000 . Since the significance value is $0.000<0.05$, integrity has a positive and significant direct effect on teaching effectiveness. The hypothesis is also supported by examining the $\mathrm{t}$-count under the conditions $\mathrm{t}$-count $>\mathrm{t}$-table. The $\mathrm{t}$-count of variable $\mathrm{X} 2$ versus variable X3 is 5.962. T-table (123) at the 0.05 significance level is 1.980; and since t-count $>t$-table, the hypothesis can be accepted. This notion implies that integrity has a positive, direct, and significant effect on teaching effectiveness. According to the calculation, the path coefficient value ( $\rho 32)$ is 0.463 , and the correlation coefficient (r23) is 0.551 .

Table 4 shows that transformational leadership directly affects integrity based on the significant value between the variables of transformational leadership and integrity. With the significance value of $0.000<0.05$, it can be concluded that transformational leadership has a positive, significant, and direct effect on integrity. Another way to examine the hypothesis is to look at the $\mathrm{t}$-count with the conditions $\mathrm{t}$-count $>\mathrm{t}$ table. Because the t-count of the variable X1 to X2 is 4.013 and t-table (123) at the 0.05 significance level is $1.980, \mathrm{t}$-count $>\mathrm{t}$-table. The hypothesis is accepted because $\mathrm{t}$-count $>\mathrm{t}$-table, implying that transformational leadership has a positive, significant, and direct effect on integrity. This can also be seen from the calculation that the path coefficient value ( $\rho 21)$ is 0.343 , and the correlation coefficient ( $r 12)$ is 0.343 .

Table 5 shows that the value of R Square is 0.362 . This demonstrates that X1 and X2 have a $36.2 \%$ effect on X3; the remaining $63.8 \%$ is influenced by variables that are not examined. The residual value (e1) can also be seen in this table. Using the equation e $1=0.638$, the path diagram for this research model is presented in Figure 1.

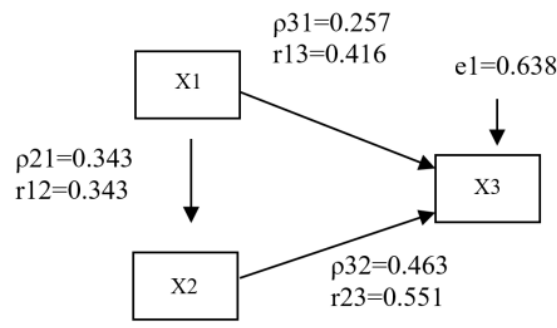

Figure 1. Model intervariable relationships based on the results of the path analysis

\subsection{Discussion}

The present work found the relationship between variables based on related theories and the results of the path analysis in this study. The analysis of the influence of the transformational leadership variable (X1) on teaching effectiveness (X3) reveals that the transformational leadership of the study program has a significant and positive impact on the teaching effectiveness of lecturers at As Syafi'iyah Islamic University. This is seen in the t-test results, which show a significance value of 0.001 . Since the significance value of 0.001 is less than 0.05 , it is logical to claim that the transformational leadership of the study program has a positive and significant effect on the teaching effectiveness of lecturers at the research site. This notion can also be seen from the $\mathrm{t}$-count obtained under the condition that if $\mathrm{t}$-count $>\mathrm{t}$-table, the variable $\mathrm{X} 1$ contributes to X3. As the t-count value (3.316) is greater than the t-table (123) value of 1.980 , the transformational leadership of the study program has a positive and significant effect on the teaching effectiveness of the lecturer at As Syafi'iyah Islamic University. It means that the higher the level of transformational leadership of the study program, the more influential the lecturer's teaching.

The obtained results are based on Setiawan's relevant research, transformational leadership has a moderate correlation coefficient with school effectiveness [35]. Effective teaching determined the overall school effectiveness. By that, quality implementation of transformational leadership improves school and 
teaching effectiveness. One role of principal leadership is to motivate teachers to achieve their goals to ensure effective learning activities [36]. The teaching effectiveness referred to in this study is the effectiveness of teaching at As Syafi'iyah Islamic University. It is hoped that improved transformational leadership of each study program's results in better teaching effectiveness. Schools with good principal leadership are capable of developing effective school management because they are aided by various factors such as technology implementation and school culture, information systems, and organizations [37]. Successful learning in higher education necessitates transformative leaders who raise employee awareness by expressing great ideals and morals such as glory, solidarity, and humanity [38]. As a result, transformational leadership is one of the factors that influence the effectiveness of teaching.

Leaders in educational institutions play a role as administrators and supervisors in motivating their staff to bring out their best performance. Teachers are encouraged by educational leaders to understand the effectiveness, sense of society, attention, professional development, and improvement of education [39]. This means that a leader in an educational institution is one of the most important factors that determine learning processes directly or indirectly. The reason is that the teachers' ability to develop and provide effective instruction depends on how the leader influences them. Transformational leadership in educational settings fosters a sense of effectiveness by empowering school staff, resulting in improved educational outcomes [40]. Transformational leadership has an indirect impact on student learning outcomes, which is one indicator of how well education is going.

The t-test results also show that the impact of the lecturer integrity variable (X2) on the teaching effectiveness variable is significant (X3). Looking at the significance value, it is clear that the lecturers' integrity influences the effectiveness of teaching due to the significance value of 0.000 , which is below 0.05 . This is also evident from the t-count, as the t-count (5.962) is greater than t-table (1.980). Simply put, the greater the lecturer's integrity, the greater the effectiveness of the teaching.

This research is in line with Firdaus, Sumardi, and Istiadi, that there is a significant and positive relationship between integrity and teaching effectiveness [15]. In other words, integrity does influence teaching effectiveness. The higher the integrity of an educator, the higher the effectiveness of the teaching a person gives. With that in mind, educators should focus their efforts on providing the best role model demonstrating integrity, respect, compassion, and sensitivity to students, as these values are essential in learning [41]. A lecturer with integrity can provide effective learning, but those with low integrity find it challenging to ensure quality education. As an educator in higher education, a lecturer is demanded to demonstrate integrity. The simple way to attain such a goal is to keep up with the norms and rules in the workplace.

Educators claim that discipline is one of the challenges in promoting effective teaching [42]. Discipline determines the integrity of a person. Somayeh, et al. opined that being disciplined contributes to the learning process [43]. Wijiyono, Hardhienata, and Retnowati found that integrity is closely related to teacher performance or performance [44]. This signifies that educator with integrity have no issues in selfdevelopment. Self-esteem (integrity) will assist teachers in carrying out their tasks [45]. This notion is in line with Okeyo, Mathooko, and Sitati that integrity is the aspect that makes a person live healthier, free of burden, and live his life without pretense, and remain consistent in condition any despite emphasis [46]. All these statements illustrate the importance of integrity for an educator. Lecturers with integrity will give their best performance as they are not perplexed with issues, such as the feeling of guilt, a lack of ethics, and a personality that does not fit their job.

The effect of transformational leadership (X1) on the integrity variable (X2) is also seen from the t-test results. Looking at the significance value, it is clear that transformational leadership has an impact on integrity since the significance value is 0.000 , which is less than 0.05 . Thereby, transformational leadership has a significant and positive impact on integrity. This is also evident from the value of t-count (4.013) that is greater than t-table (1.980).

These findings are in line with the results seen in Parry and Thomson's study, they discovered a significant and positive relationship between perceived integrity and transformational leadership behavior in the research sample [47]. This demonstrates that several factors, including transformational leadership, have an impact on integrity. Further, the higher the level of transformational leadership, the higher the integrity. The principal's leadership is an essential component in the teaching and learning process; thus, any changes are insignificant if the leadership is poor [48]. In this case, the lecturers' integrity is undoubtedly influenced by the leadership style of their superiors. Transformational leadership is central to integrity since lecturers with self-integrity are the key to quality learning in higher education. It is also worth mentioning that the leadership of superiors also takes part in actualizing the goal.

According to Huberts, integrity is a professional responsibility; teachers are responsible for all of their duties at the school [49]. Leaders are more likely to believe in their employees' abilities and expertise to complete the job [50]. This means that the leader expects his or her followers to work with integrity. 
Aswegen and Engelbrecht discover that all dimensions of transformational leadership were inextricably linked to integrity [51]. This notion explains the extent to which quality leadership contributes to the attainment of organizational goals, which also serve as the principles and norms in society. The core of transformational leadership is devoted to facilitating the development of corporate members [52]

\section{CONCLUSION}

The study found that transformational leadership and integrity have direct and positive impact on the teaching effectiveness. Transformational leadership has a direct and positive impact on the integrity. Improving the implementation of transformational leadership is effective to enhance self-integrity of lecturers at As Syafi'iyah Islamic University.

It is suggested to implement the better transformational leadership to achieve the better the teaching effectiveness. To improve the effectiveness of lecturers' teaching, implementing transformational leadership is one option for the head of the study program, because it is effective in improving the effectiveness of teaching. The head of the study program should approach the lecturers through good communication practices. Such an approach develops the relationship between the head of the study program and lecturers, this helps motivate the lecturers in teaching. Lecturers as educators must have high integrity to improve teaching effectiveness. Building integrity is possible by demonstrating positive characteristics in workplace (adhering to the norms in the workplace).

This research has several limitations. First, since the present work was conducted during the COVID-19 pandemic, the total sample is not representative (only 5\%). Second, this research relies on questionnaires and observation as the primary data collection techniques, thus it can be said that not all related data were retrieved. Future studies are expected to involve more sample and comprehensive data collection in examining topics relevant to the present work.

\section{ACKNOWLEDGEMENTS}

Authors would like to express gratitude to all teachers who had been involved in this study. Authors also thankful to each and every party that helped me accomplish this work.

\section{REFERENCES}

[1] A. Sarid, "A theory of education," Cambridge Journal of Education, vol. 48, no. 4, pp. 479-494, 2017, doi: 10.1080/0305764X.2017.1356267.

[2] F. Idris, Z. Hassan, A. Ya'acob, S. K. Gill, and N. A. Mohd Awal, "The role of education in shaping youth's national identity," Procedia - Social and Behavioral Sciences, vol. 59, pp. 443-450, 2012, doi: 10.1016/j.sbspro.2012.09.299.

[3] S. Moran, "Purpose-in-action education: Introduction and implications," Journal of Moral Education, vol. 47, no. 2, pp. 145-158, 2018, doi: 10.1080/03057240.2018.1444001

[4] K. Komoldit, M. Tawisook, and N. Pilanthananond, "Graduate School Management Characteristics to Ensure Production of Quality Graduates for Sustainable Competitiveness," Mediterranean Journal of Social Sciences, vol. 9, no. 4, pp. 121-129, 2018.

[5] A. J. Kola, O. S. Sunday, and G. I. Ayinde, "Teachers' Effectiveness and its Influence on Students' Learning," Advances in Social Sciences Research Journal, vol. 2, no. 4, pp. 88-95, 2015, doi: 10.14738/assrj.24.1082.

[6] M. Mundy, L. Kupczynski, and R. Kee, "Teacher's perceptions of technology use in the schools," Sage Open, vol. 2, no. 1, pp. 1-8, 2012, doi: 10.1177/2158244012440813.

[7] S. D. B. Eristi, A. A. Kurt, and M. Dindar, "Teachers' views about effective use of technology in classrooms," Turkish Online Journal of Qualitative Inquiry, vol. 3, no. 2, pp. 30-41, 2012, doi: 10.17569/tojqi.51671.

[8] K. Chaturvedi, D. K. Vishwakarma, and N. Singh, "COVID-19 and its impact on education, social life and mental health of students: A survey," Children and Youth Services Review, vol. 121, pp. 1-6, Feb. 2021, doi: 10.1016/j.childyouth.2020.105866.

[9] M. U. Ochoma, "Teacher's voice quality and teaching effectiveness," African Research Review, vol. 13, no. 3, pp. 141-148, 2019 doi: 10.4314/afrrev.v13i3.12.

[10] D. Hammer, et al., "Recognition of teaching excellence," American Journal of Pharmaceutical Education, vol. 74, no. 9, pp. 1-11, 2010, doi: 10.5688/aj7409164

[11] S. Aimah and B. Purwanto, "Evaluating teachers' performance: A need for effective teaching," A Journal of Culture, English Language Teaching and Literature, vol. 19, no. 1, pp. 160-173, 2019, doi: 10.24167/celt.v19i1.1369.

[12] K. S. Nagler, "Effective classroom-management \& positive teaching," English Language Teaching, vol. 9, no. 1, pp. 163-172, 2016, doi: 10.5539/elt.v9n1p163.

[13] E. Gultom and S. Saun, "The Role of Classroom Management in Creating an Effective English Learning," Journal of English Language Teaching, vol. 5, no. 1, pp. 18-24, 2016, doi: 10.24036/jelt.v5i1.7261. 
[14] B. U. Onyekuru and J. O. Ibegbunam, "Teaching Effectiveness of Secondary School Teachers in Emohua Local Government Area of Rivers State, Nigeria,” European Scientific Journal, vol. 9, no. 28, pp. 212-226, 2013.

[15] Y. Firdaus, S. Sumardi, and Y. Istiadi, "Teacher teaching effectiveness in terms of adversity quotient and integrity," (in Indonesia), Jurnal Manajemen Pendidikan, vol. 7, no. 1, pp. 700-706, 2019, doi: 10.33751/jmp.v7i1.954.

[16] Y. Arifani, F. N. Mohd Khaja, S. Suryanti, and A. Wardhono, "The Influence of Blended In-service Teacher Professional Training on EFL Teacher Creativity and Teaching Effectiveness," The Southeast Asian Journal of English Language Studies, vol. 25, no. 3, pp. 126-136, 2019, doi: 10.17576/3L-2019-2503-10.

[17] S. Sabir, "A study on Ethical leadership perceptions and its impact on teachers commitment in Pakistan," International Journal of Educational Leadership and Management, vol. 9, no. 1, pp. 28-53, 2021, doi: 10.17583/ijelm.2020.4525.

[18] M. S. Ibrahim, S. Ghavifekr, S. Ling, S.Siraj, and M. Ibrahim K. Azeez, "Can transformational leadership influence on teachers' commitment towards organization, teaching profession, and students learning? A quantitative analysis," Asia Pacific Education Review, vol. 15, no. 2, pp. 177-190, 2013, doi:10.1007/s12564-013-9308-3.

[19] N. Nurhayati, C. Z. Harun, and B. Bahrun, "The Principal's Leadership Strategy in Improving Quality: A Study at Aron State Elementary School Pidie Aceh Indonesia," in Proceedings of the 3rd International Conference on Educational Management and Administration (CoEMA 2018), 2018, pp. 42-45, doi: 10.2991/coema-18.2018.11.

[20] S. Surasni, "The effect of transformational leadership, learning organizational, and organization commitment towards lecturers' job performance at the University of Pamulang, South Tangerang," INOVASI: Jurnal Ilmiah Ilmu Manajemen, vol. 5, no. 1, pp. 51-68, 2018, doi: 10.32493/Inovasi.v5i1.p47-64.1710.

[21] C.-H. S. Liu and Y.-C. Huang, "The influence of transformational leadership on subordinate creative behaviour development process," Tourist Management Perspectives, vol. 36, pp. 1-11, 2020, doi: 10.1016/j.tmp.2020.100742.

[22] S. Andriani, N. Kesumawati, and M. Kristiawan, "The Influence of The Transformational Leadership and Work Motivation on Teachers Performance," International Journal of Scientific \& Technology Research, vol. 7, no. 7, pp. 19-29, 2018

[23] F.-Y. Lai, H.-C. Tang, S.-C. Lu, Y.-C. Lee, and C.-C. Lin, "Transformational leadership and job performance: The mediating role of work engagement," Sage Open, vol. 10, no. 1, pp. 1-11, 2020, doi: 10.1177/2158244019899085.

[24] T. Bush, "Instructional and Transformational Leadership: Alternative and Complementary Models?" Educational Management and Leadership, vol. 42, no. 4, pp. 443-444, 2014, doi: 10.1177/1741143214526830.

[25] Z. Zengtian and G. Xiuyuan, "The Impact of Transformational Leadership on Employee Voice Behavior: The Role of Organizational Identification and Procedural Justice," International Business and Management, vol. 9, no. 2, pp. 168-172, 2014, doi: 10.3968/6056.

[26] A. Purwanto, R. Primahendra, A. Sopa, S. W. Kusumaningsih, and R. Pramono, "The influence of transformational, transactional, authentic and authoritarian leadership styles on teacher performance in Madrasah Aliyah in Tangerang," (in Indonesia), Evaluasi: Jurnal Manajemen Pendidikan Islam, vol. 4, no. 1, pp. 20-44, 2020, doi: 10.32478/evaluasi.v4i1.342.

[27] I. S. Maris, A. Komariah, and A. Bakar, "Principal's transformational leadership, teacher performance and school quality," (in Indonesia), Jurnal Administrasi Pendidikan, vol. 23, no. 2, pp. 173-188, 2016, doi: 10.17509/jap.v23i2.5645.

[28] Yulianti and Wuryanti, "The Influence of Transformational Leadership, Behavioral Integrity and Trust in Leaders in Improving HR Performance (Study of BLHKP, BKPPD and BPMP of South Konawe Regency, Southeast Sulawesi Province)," (in Indonesia), in 2nd Conference in Business, Accounting, And Management (CBAM), vol. 2, no. 1, 2015, pp. 282-300. [Online]. Available: http://jurnal.unissula.ac.id/index.php/cbam/article/view/313.

[29] I. Isjoni, A. Daud, and A. Azhar, "Integrity and Performance of High School Teachers in Pekanbaru," Indonesian Journal of Economics, Social, and Humanities, vol. 1, no. 1, pp. 51-57, 2019, doi: 10.31258/ijesh.1.1.5.

[30] Y. S. Anggreini, Y. S. Purbandari, and T. S. Prihatiningsih, "The Perceptions of students and Teachers about The Level of The Sanctions for academic Integrity Violans: An Explanatory Sequential Design Study in a Nursing Education Program," Jurnal Pendidikan Kedokteran Indonesia, vol. 6, no. 2, pp. 84-92, 2017, doi: 10.22146/jpki.32248.

[31] S. Riadi, "The analysis influence of leadership and its impact on performance through job satisfaction and integrity of elementary school teachers in Junrejo District, Batu City," (in Indonesia), Jurnal Ilmu Manajemen (JIMMU), vol. 2, no. 2, pp. 127-135, 2019, doi: 10.33474/manajemen.v2i2.1587.

[32] M. H. Oktavia, "The influence of integrity, confidentiality, task complexity, motivation and unclear role on the performance of auditors in the Inspectorate of Central Java Province," (in Indonesia), Jurnal Akuntansi Bisnis, vol. 16, no. 2, pp. 161-179, 2018, doi: 10.24167/jab.v16i2.2253.

[33] H. AL-Abrrow, H. Abdullah, and N. Atshan, "Effect of organisational integrity and leadership behaviour on organisational excellence: Mediator role of work engagement," International Journal of Organizational Analysis, vol. 27, no. 4, pp. 972-985, 2019, doi: 10.1108/IJOA-08-2018-1518.

[34] L. W. J. C. Huberts, "Integrity: What it is and Why it is Important," Public Integrity, vol. 20, no. Supp 1, pp. S18-S32, 2018, doi: 10.1080/10999922.2018.1477404.

[35] A. Setiawan, "Contribution of Principal Transformational Leadership and School Climate on School Effectiveness," (in Indonesia), Jurnal Administrasi Pendidikan, vol. 23, no. 1, pp. 130-140, 2016, doi: 10.17509/jap.v23i1.5581.

[36] O. Chanthea, "Principal's Leadership in Improving Teacher Discipline," Jurnal Pendidikan Humaniora, vol. 1, no. 4, pp. 396-404, 2013. 
[37] C. Sunaengsih, M. Anggarani, M. Amalia, S. Nurfatmala, and S. D. Naelin, "Principal Leadership in the Implementation of Effective School Management," Mimbar Sekolah Dasar, vol. 6, no. 1, pp. 79-91, 2019, doi: 10.17509/mimbar-sd.v6i1.15200.

[38] F. Nurtjahjani, Noermijati, D. Hadiwidjojo, and D. W. Irawanto, "Transformational Leadership in Higher Education: (A Study in Indonesian Universities)," in 3rd Asia Pacific International Conference of Management and Business Science (AICMBS 2019), Kota Batu, East Java, 2019, pp. 95.

[39] M. Alzoraiki, O. Ab. Rahman, and M. A. Mutalib, "The Effect of the Dimensions of Transformational Leadership on the Teachers' Performance in the Yemeni Public Schools," European Scientific Journal, vol. 14, no. 25, pp. 322-334, 2018, doi: 10.19044/esj.2018.v14n25p322.

[40] F. Alsaeedi and T. Male, "Transformational Leadership and Globalization: Attitudes of School Principals in Kuwait," Educational Management Administration and Leadership, vol. 41, no. 5, pp. 640-657, 2013, doi: $10.1177 / 1741143213488588$.

[41] N. M. Hazrul Nik Hashim, S. S. Alam, and N. Mohd Yusoff, "Relationship between Teacher's Personality, Monitoring, Learning Environment, and Students' EFL Performance," Gema Online Journal of Language Studies, vol. 14, no. 1, pp. 101-116, 2014, doi: 10.17576/GEMA-2014-1401-07.

[42] R. Chandra, "Classroom Management for Effective Teaching," International Journal of Educational and Psychological Research (IJEPR), vol. 4, no. 4, pp. 13-15, 2015.

[43] G. Somayeh, J. Sayyed Mirshah, S. S. Mostafa, and A. Azizollah, "Investigating the Effect of Positive Discipline on the Learning Process and its Achieving Strategies with Focusing on the Students' Abilities," International Journal of Academic Research in Business and Social Sciences, vol. 3, no. 5, pp. 305-314, 2013, doi: 10.13140/2.1.3008.5128.

[44] Wijiyono, S. Hardhienata, and R. Retnowati, "Improvement of Teacher's Performance through Development of Decision Making, Integrity, and Organizational Climate Using Sequential Explanatory Analysis," International Journal of Managerial Studies and Research (IJMSR), vol. 7, no. 4, pp. 40-46, 2019, doi: 10.20431/23490349.0704006

[45] S. Sarmidi, S. Suratno, and R. Riyadi, "The Influence of Motivation, Discipline, Adversity Quotient and Integrity Toward Teachers' Competency Test of Physical Education and Sport Teachers," Jurnal Pendidikan: Teori, Penelitian, dan Pengembangan, vol. 5, no. 5, pp. 714-724, 2020, doi: 10.17977/jptpp.v5i5.13579.

[46] O. Okeyo, P. Mathooko, and N. Sitati, "The Effects of Performance Appraisal System on Civil Servants Job Performance and Motivation in Kenya: A Case Study of Ministry of State for Public Service," In Proceedings of Kabarak University 1st Annual International Research Conference, 2012, p. 370.

[47] K. W. Parry and S. B. Proctor-Thomson, "Perceived Integrity of Transformational Leaders in Organisational Settings," Journal of Business Ethics, vol. 35, no. 2, pp. 75-96, 2002, doi: 10.1023/A:1013077109223.

[48] O. Amtu, A. Siahaya, and J.A. Taliak, "Improve Teacher Creativity through Leadership and Principals Management," Academy of Educational Leadership Journal, vol. 23, no. 1, pp. 1-17, 2019.

[49] L.W.J.C. Huberts, "Integrity: What it is and Why it is Important," Public Integrity, vol. 20, pp. S18-S32, Jul. 2018, doi: 10.1080/10999922.2018.1477404.

[50] E. Elpisah and H. Hartini, "Principal Leadership Style and Its Effect on Teachers Performance," Journal of Applied Management (JAM), vol. 17, no. 3, pp. 506-514, 2019, doi: 10.21776/ub.jam.2019.017.03.15.

[51] A. S. van Aswegen and A. S. Engelbrecht, "The relationship between transformational leadership, integrity and an ethical climate in organisations," SA Journal of Human Resource Management, vol. 7, no. 1, pp. 221-229, 2009, doi: 10.4102/sajhrm.v7i1.175.

[52] J. A. Ross and P. Gray, "Transformational leadership and teacher commitment to organizational values: The mediating effects of collective teacher efficacy," School Effectiveness and School Improvement, vol. 17, no. 2, pp. 179-199, 2006, doi: 10.1080/09243450600565795. 